non-linked contracts are discussed. Although such guarantees are usual in North America, and although a demand is known to exist in Britain, the potential damage from high and volatile interest rates is judged to be very significant.

The paper concludes in the view that in meeting market demand for flexible options the profession should use modern statistical methods to fully analyse all the risks involved.

\title{
THE FINANCIAL MANAGEMENT OF A DEVELOPING LIFE OFFICE
}

\author{
by \\ D. J. LE GRYS
}

(Synopsis of a paper presented to the Society on 4 November 1980)

The Financial Management of a Developing Life Office was produced in 1979 and was principally written for managers and directors of newly established Life Offices in the United Kingdom. Most of these offices write non profit and unit-linked types of life assurance business and this book concentrates on the problems related to these policies.

The aim was to produce an outline of the main factors affecting a life office as it developed, and to highlight constraints and dangers.

\section{Chapter 1}

The capital requirements for a developing life office are explained and the concept of a 'corridor for development' is defined. Although a new office may be attracting business at profitable terms, the office must keep its production below a maximum production limit otherwise it will exhaust the shareholders' capital. On the other hand the office must reach a certain minimum production limit if it is to trade successfully and to earn profits in the long term.

The five main factors that affect the development of a new life office are defined as the marketing terms, expense performance, investment and reserve requirements, tax position and inflation. 


\section{Chapter 2}

The need for an adequate premium level is explained. An adequate premium is defined as the premium which, allowing for expected lapses, commission, claims, expenses, frequency of premium and all other variables is likely to leave the life office with an adequate return on capital. The amount of potential profit per sale should also be reasonable relative to the sales effort and the cost of administering the policy.

An example of a projection for testing the adequacy of the premium is shown together with some typical assumptions for a savings policy. The general marketing factors and their effect on both the initial capital requirement and the long-term profits are explained.

\section{Chapter 3}

The statutory responsibility of the Appointed Actuary is briefly outlined. Valuation methods and techniques are not dealt with in detail, but the need for adequate reserves is explained. The threats to a life office's solvency are grouped under two broad headings. Firstly under 'Creeping Insolvency' are those factors such as poor trading and management, expense inflation and inadequate returns which lead to a gradually deteriorating position and ever larger transfers from shareholders being required to cover deficiencies in the life fund.

The factors shown as being 'Potentially Crippling' are mismatched investments and guarantees of maturity values, death benefits, surrender values or minimum investment returns. Liquidity problems and other options against the life office are also included in this heading.

The investment responsibility for a life office is shown to be a threefold responsibility of the Directors and general management, the Actuary and the investment managers. The relationship between the responsibilities can be seen from a simplified example.

\section{Chapter 4}

One of the major forces affecting the amount of capital and the emergence of profits is the taxation position of the developing office. An example is given showing the new business strain to offices in favourable and unfavourable tax positions. The need for a developing life office to issue single-premium policies is explained and an example of the pricing considerations for income bonds is given. 


\section{Chapter 5}

The various forms of expense analysis are considered and specimen analyses for a small office are shown. Considerable emphasis is placed on the comparison of actual expenses to the expense margins contained in the premium income to the office.

\section{Chapter 6}

Inflation is singled out as the most important threat to life offices and the biggest single factor delaying the emergence of profits. The damaging effects of inflation are considered to be:

(i) Inflation could change policyholders' attitudes to long-term savings.

(ii) Inflation can make all existing business unprofitable.

(iii) Inflation can produce monetary growth faster than budgeted expansion and thereby increase financing strains.

The effect of inflation on profitability, solvency, capital requirements and the tax position are discussed. It is suggested that to combat inflation, offices should build into the premium formula adequate expense assumptions that anticipate some degree of inflation and that on unit-linked products the office should reserve the right to increase margins for expenses if inflation exceeds expectation. It is argued that U.K. offices would be better protected if they issued increasing 'savings' policies of the type which are now widespread in the rest of Europe. The increasing policies have the benefit of:

(i) Increasing the premium income (and the expense contribution) to the office automatically.

(ii) Giving the policyholder a more realistic savings and life assurance plan.

\section{Chapter 7}

The final chapter is concerned with measuring the performance of a developing life office. The four main areas where information is required are indentified.

In addition to the normal reporting systems a case is made for a regular 'net asset' evaluation of the office so that shareholders can monitor the performance of their investment. The prime responsibility of the Directors, managers and Actuary is to ensure that 
obligations to existing policyholders are met in full. Having satisfied this overriding principle it is a valid question for shareholders to ask if their interests are best served by keeping the life office open and writing the maximum level of new business, writing a restricted level of business or closing the office to new business altogether. The importance of continuing viability studies and corporate plans to answer these critical questions is emphasized.

\section{INDEX-LINKING IN THE U.K.}

by

\section{H. NEWTON}

(Synopsis of a paper presented to the Society on 16 December 1980)

During recent years, the United Kingdom has experienced high and variable rates of inflation. Consideration has therefore been given to techniques, like indexation, which may help to reduce the impact of inflation.

The paper surveys the many areas where some form of index-linking has been introduced in this country. It then discusses the theoretical economic arguments for and against indexation. Whether indexation will help to reduce inflation or increase the inflationary pressures is not clear. The major argument for introducing indexlinking is that it helps reduce the inequities caused by inflation, in particular for long-term contracts where the risks and uncertainties are even greater. The indexation of specific short-term contracts-wages and taxes - is therefore only briefly considered and the paper concentrates on the areas of pensions and fixed interest investments.

Since the paper was presented there have been two issues of index-linked gilts, restricted to pension funds and the pensions liabilities of insurance companies; at issue the first gave a real return of $2 \%$, the second $2 \frac{7 \%}{8} \%$. At the latter rate of return pension funds will nearly obtain the return they expect on average from all their assets and it is guaranteed. One would expect pension funds to be prepared to invest a reasonable proportion of their assets into such a security.

Pensions are at the forefront of the public discussion about indexation. There is a division between the public sector which in 